\title{
Climatic and Anthropic Influence on the Geodiversity of the Maranhão
} Amazon Floodplain

\author{
V. A. R. Silva ${ }^{1}$, L. B. Portela ${ }^{2}$, J. L. Almeida ${ }^{3}$, C. H. L. Silva Junior ${ }^{4}$, J. S. dos Santos ${ }^{3}$, J. R. N. Santos ${ }^{3}$, \\ M. L. S. de Araújo ${ }^{5}$, F. E. C. S. Feitosa ${ }^{3}$, C. W. B. Bezerra ${ }^{2} \&$ F. B. Silva ${ }^{3}$ \\ ${ }^{1}$ Instituto Federal do Maranhão, Pinheiro, Maranhão, Brazil \\ ${ }^{2}$ Universidade Federal do Maranhão, São Luís, Maranhão, Brazil \\ ${ }^{3}$ Universidade Ceuma, São Luís, Maranhão, Brazil \\ ${ }^{4}$ Tropical Ecosystems and Environmental Sciences Laboratory, Remote Sensing Division, National Institute for \\ Space Research, São José dos Campos, Brazil \\ ${ }^{5}$ Universidade Federal de Campina Grande, Campina Grande, Paraíba, Brazil \\ Correspondence: V. A. R. Silva, Instituto Federal do Maranhão, Campus Pinheiro, Rodovia MA-006, s/n, Pinheiro, \\ Maranhão 65200-000, Brazil. Tel: 98-981-381-465. E-mail: vilenaribeirosilva@gmail.com
}

Received: June 23, 2019

doi:10.5539/jas.v11n18p105
Accepted: September 19, $2019 \quad$ Online Published: November 15, 2019

URL: https://doi.org/10.5539/jas.v11n18p105

\begin{abstract}
The Maranhense Amazon floodplain shelters a Ramsar site established by the United Nations for the protection of wetland biodiversity. Despite its protected ecological status, the impacts from deforestation, burning, the agricultural and livestock industries, are on the rise. Knowledge of the spatial distribution and temporal dynamics of these impacts are important to improve the understanding of how this region is affected. Data on increasing deforestation and hot pixels were used to evaluate the anthropogenic pressure under the geodiversity of the region, relating them to the environmental variables (rainfall, Normalized Difference Vegetation Index and Deforestation annual deforestation rate) measured through the rainfall data and the Normalized Difference Vegetation Index (NDVI). In this study, the potential of remote sensing and geographic information system. The time series were used from 2001 to 2016 for all variables. We observed a strong negative and significant correlation between hot pixels and NDVI, while hot pixels increase, the vegetation indexes tend to decrease. In 2006 an abrupt fall in the NDVI occurred due to the marked increase in the deforested area. In 2010, the NDVI reached its highest levels, because the vegetation responded to the highest rainfall observed in the period in 2009 . Unit 4 presented the highest pixels number in the period evaluated (2,978 pixels; $55 \%$ of the total). There is a significant correlation between NDVI and rainfall.
\end{abstract}

Keywords: deforestation, fires, NDVI, Pinheiro, Ramsar, remote sensing

\section{Introduction}

The loss of natural habitats due to anthropic interference greatly impacts the Amazonian biome. The Maranhense Floodplain region, also known as "Baixada Maranhense" (in Portuguese), located in the Maranhense Amazon, is recognized internationally as one of the 25 Ramsar Sites in Brazil (Convention on Wetlands of International Importance), which host some of the most biologically diverse environments on the planet (Farias Filho, 2013). This region also constitutes a State Environmental Protection Area, established by the Decree 11.900 of November 6, 1991.

Even with this recognized ecological status, there are several environmental impacts resulting from anthropic pressures in the region, where deforestation and fires are the most relevant contributors to biodiversity loss. Between 2008 and 2012, this Environmental Protection Area was among the three state conservation units that had the most burnt spots in the state. During this period, 19,048 hot pixels were registered in the state Conservation Units, which corresponded to $19.5 \%$ of all the hot pixels identified in this period for Maranhão (Silva et al., 2016).

The changes in the vegetation structure may be directly reflected in the biodiversity loss due to a reduction in the percentage of forest cover, lower habitat heterogeneity, and consequently a reduction of the communities; thus, irreversibly altering the ecological balance of the biome (Vieira et al., 2005; Muniz, 2006; Cardozo et al., 2014). 
Accurate and up to date information on the location and extension of the impacts from deforestation and fire in this region are critical to assessing landscape change and its ecological effects, resulting economic losses, changes in land use and cover and how these impacts interfere with biodiversity loss. Through remote sensing data, it is possible to obtain a wide view on the deforestation in a region, the space-time distribution of burnt fields, as well as the responses of the vegetation to such impacts, being possible to evaluate their interactions and consequences (Piromal et al., 2008).

In complex environments such as the Amazonian Floodplains, the use of the spatial concept of geodiversity favors an integrated understanding of the environment, as it can reveal the mineral resources, geology, and natural landscapes inherent to a specific region composed by specific types of rocks, relief, soils, and climate (Gray, 2004; Silva, 2008). The geodiversity assessment is considered a potentially effective tool to support decision-making processes, management, and conservation of natural areas or regions at both local or supra-regional scales (Serrano \& Ruiz-Flaño, 2007).

The ecological importance of this region is the marked presence of floodplains that are submerged during the rainy season (December to June), forming one of the largest lake systems in Brazil. The rivers and lakes formed in the fluvial plains during the rainy season assume great socioeconomic importance as the economic activities of the region are intrinsically linked to these environments (Carvalho Neta et al., 2015).

In this sense, the anthropic activities maintain a close relationship with the flood and drought courses of the lakes, due to the climatic characteristics (hot and humid climate with rainfall range of $2000 \mathrm{~mm}$ per year). This climatic characteristic associated with the geomorphological, geological, and pedological characteristics favors the development of fishing, agriculture, and livestock rearing (Farias Filho, 2013).

The lowland agriculture stands out in the Baixada Maranhense for its particularly fertile soils. Furthermore, its products, especially rice, are introduced in the market in periods of low supply (Farias Filho \& Ferraz Jr., 2009). The exploitation of lakes, floodplain soils and vegetation occurred irregularly, causing several environmental changes in the region that compromised the balance of fragile ecosystems. Especially since the 1960s, with the construction of the state highway MA 014 and with the significant increase of the population of the region and its consequent urbanization (Carvalho Neta et al., 2015).

The study area presents a warm and humid climate, with two well-defined climatic seasons: the dry season between July and November and the wet season, from December to June (Viegas Carvalho et al., 2011). The vegetation reveals the nature of the transition between the semi-arid climate of the northeast and the humid and sub-humid climates of the north region. The region presents a high phytophysiognomy diversity with areas of dense and open ombrophilous forest, cerrado, mangroves, and flood fields (Carvalho Neta et al., 2015).

Thus, this work focusses on answering the following questions: 1) Do the burns occur randomly in the floodplains of the Baixada Maranhense, or is there a well-defined space-time pattern? 2) Are the studied areas being affected homogeneously? 3) Is the studied area affected by climate or anthropogenic actions? Therefore, this study aimed to determine the space-time distribution of deforestation and burning and their relation to climatic variables in the different geological-environmental units (Units) of the floodplains of Maranhense Amazon.

\section{Methods}

\subsection{Study Area}

The municipality of Pinheiro was chosen as the sample unit of the floodplain region of Maranhense Amazon (Figure 1). Pinheiro is part of the Maranhense Northern Mesoregion and the Baixada Maranhense microregion with an area of $1,552.95 \mathrm{~km}^{2}$, between $02^{\circ} 31^{\prime} 17^{\prime \prime} \mathrm{S}$ and $45^{\circ} 06^{\prime} 57^{\prime \prime} \mathrm{W}$. 


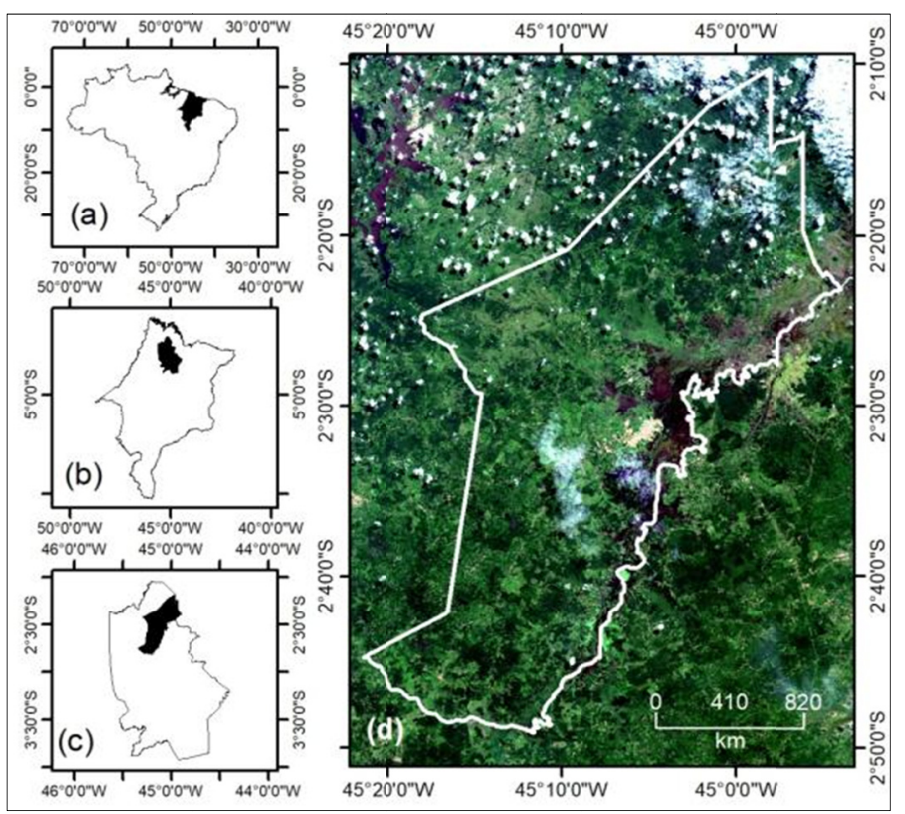

Figure 1. Map of the study area. (a) Location of the Maranhão state in Brazil. (b) Location of the Environmental Protection Area of Baixada Maranhense in Maranhão state. (c) Location of the Pinheiro municipality in Environmental Protection Area of Baixada Maranhense. (d) Study area with a Landsat natural-color composite (R-Red; G-Green; B-Blue)

Of the municipal territory $98.7 \%$ is located in the Environmental Protection Area of Baixada Maranhense, corresponding to $1.532 .67 \mathrm{~km}^{2}$. It is located predominantly on the Pericumã river basin, which is a factor of exposure of the natural resources to the potential environmental impacts. The geodiversity of Baixada Maranhense presents five Geological-Environmental Units, of which four are found in the municipality of Pinheiro. The study area represents the pedo-geomorphological characteristics found in the microregion well.

\subsection{Space-Time Dynamics of Fires Under the Local Geodiversity}

To identify the geodiversity of the study area, we used a database from the Brazil Geodiversity Project to generate a multiscale product, facing the land use and planning of mineral, transport, agriculture, tourism and environment sectors. This information was obtained from the Geological Chart from Brazil to the Millionth, and based on the information plans generated from Geology, Structures, of the Digital Terrain Model (Shuttle Radar Topography Mission), of the Geocover 2000 Mosaic and Drainage on scale 1:1,000,000 (GeoBank-CPRM/SGB) (Ramos et al., 2006).

A database was constructed in a SIG environment, inserting shapefile format files corresponding to the territorial limits of the study area (Pinheiro-MA) and the limits of each Geological-Environmental Unit. We used hot pixels (thermal anomalies) as a proxy of fire. The hot pixels monthly data where obtained from the official Fire Database of National Institute for Space Research (INPE) from 2001 to 2016.

Then, hot pixel density matrix data for each year of study were generated through the Kernel density estimator algorithm. This indicator is easy to use and interpret and can be used to verify which areas have a higher incidence of hot pixels. Kernel analysis aims to obtain a smoothed estimate of the density of hot pixels per unit of area. This count is weighted by the distance of each event to the reference point within a given radius; a property of relevance for the analysis of the tendency of a spatial stochastic process (Abreu \& Souza, 2016).

\subsection{Relation Between Deforestation, Fires, Rainfall, and NDVI}

The deforestation rates were obtained from the PRODES/INPE project that monitors deforestation by shallow cutting in the Legal Amazon. The annual rates were estimated from the deforestation increase identified in each satellite image that covers the Legal Amazon, using Landsat and Landsat-like satellite imagery with spatial resolution varying between 20 to 30 meters (Table 1). 
Table 1. Description of the data used.

\begin{tabular}{lllll}
\hline Attribute & Satellite/Sensor & Spatial Resolution & SIG & Source \\
\hline Geodiversity & & & ArcGIS & CPRM \\
Hot pixels & Multiple satellites and sensors & & ArcGIS & INPE \\
Deforestation & Landsat and Landsat-like & 20 to 30 meters & & INPE \\
NDVI & MOD13A3 & $250 \mathrm{~m}$ & ENVI & \\
Rainfall & & & & INMET \\
\hline
\end{tabular}

The rainfall climatological data were obtained from the Zé Doca meteorological station of the National Institute of Meteorology, due to the proximity of the study area. Monthly rainfall records were used from 2001 to 2016 . In order to estimate the NDVI, the time series of product MOD13A3 was used from January 2001 to December 2016 (total of 192 time-series) and executed in the ENVI application version 4.5 (ITT VIS, 2008). The NDVI was available every 16 days with a spatial resolution of $250 \mathrm{~m}$ (Bayma \& Sano, 2015). It was calculated from the normalized ratio between the near-infrared bands and the red band, ranging between -1 and 1 (Equation 1):

$$
\mathrm{NDVI}=\frac{\rho_{\mathrm{NIR}}-\rho_{\mathrm{RED}}}{\rho_{\mathrm{NIR}}+\rho_{\mathrm{RED}}}
$$

where, $\rho_{\text {NIR }}$ and $\rho_{\text {RED }}$ are the bi-directional surface reflectance factors for the near-infrared and red bands, respectively. For the analysis of the relation between deforestation, burning, rainfall, and NDVI, the Spearman correlation coefficient was used because the values of the metrics calculated in the different variables did not present a normal distribution according to the Kolmogorov-Smirnov test. The Spearman correlation coefficient ranged from -1 to 1 . The signal indicated the positive or negative direction and the value indicates the strength of the correlation between the variables. For Cohen (1988), values between 0.10 and 0.29 can be considered low; between 0.30 and 0.49 average; and between 0.50 and 1 can be interpreted as high.

\section{Results}

\subsection{Local Geodiversity}

The geodiversity maps (defined here as the diversity of geology, geomorphology and soil characteristics) are now considered potentially useful for territorial management, particularly for protected areas. In geodiversity maps (Figure 2), it is possible to identify 5 Units present in Baixada Maranhense, where four of them were found in the study area (Pinheiro municipality).
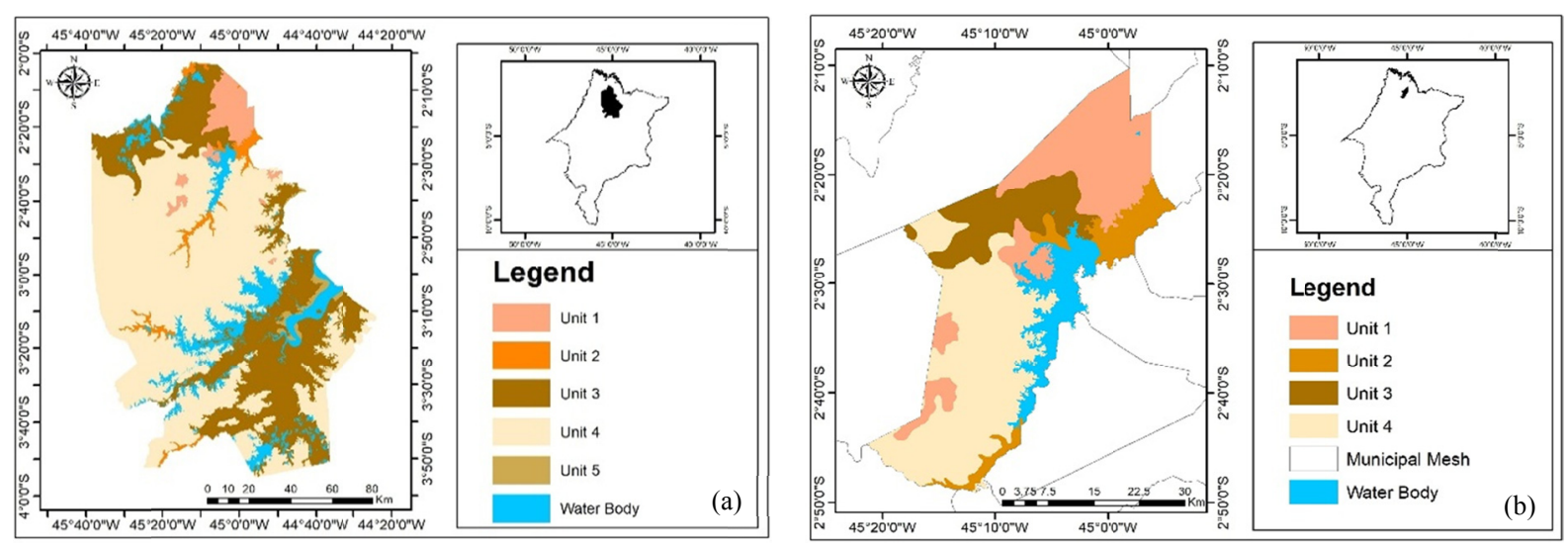

Figure 2. (a) Geodiversity Map of Baixada Maranhense and (b) Geodiversity Map of the municipality of

Pinheiro-MA

\subsection{Space-Time Dynamics of Burnt Spots}

From the best scale defined by the K function, a density map of the burn distribution was generated by means of the Kernel method, which shows where the occurrence of fires presented a higher density of "hot bed" or "cold bed" density, indicating visually that burn occurrence does not present a completely random pattern in the study area (Figure 3). 

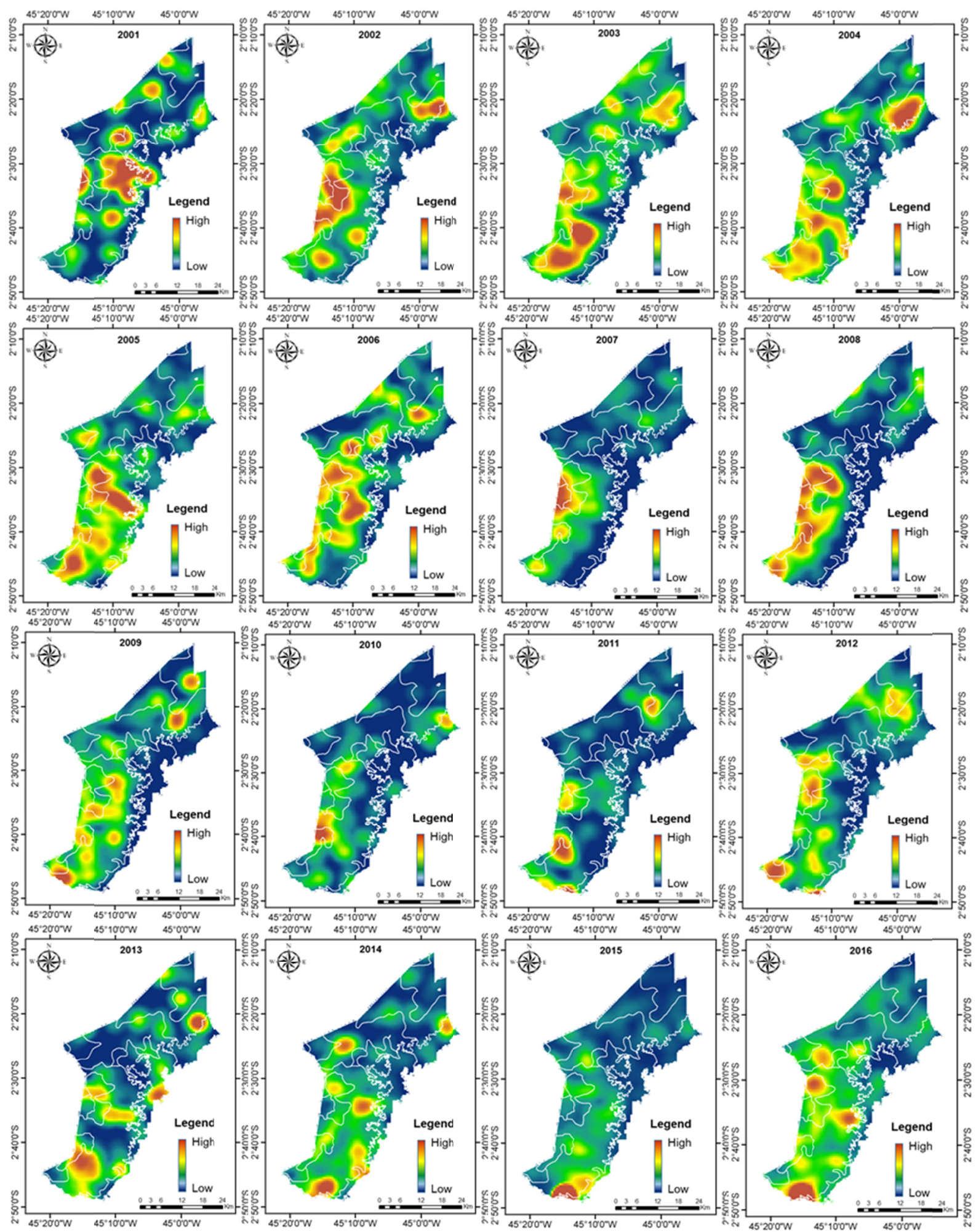

Figure 3. Density map of hot pixels in the period from 2001 to 2016. The white lines delimit the Units

The Kernel map represents the result of the interpolation of the events considered in the analysis (burned areas), where the punctual intensity of occurrence in the floodplain of Amazonia Maranhense is observed. High-density spots in red color were estimated in the eastern part, corresponding to Unit 4. Moderately-dense spots (in orange tones) appear distributed throughout the other geological-environmental units (Units 1, 2 and 3). The low density 
classes (yellow spots) were observed only in 2005 and in 2013 in the northern part of the study area corresponding to Unit 1

The Kernel method allows observing the density of heat sources, not the presence or absence of them in a region. We verified that in the time series studied, the heat sources were distributed in all the Units of the region, but with a concentration in Unit 4, being more evident this occurrence in the years of 2007, 2008 and 2015.

Regarding the number of hot pixels by Unit (Figure 4a), we found that Unit 4 presented the highest number in the period evaluated (2,978 pixels; $55 \%$ of the total). Unit 1 concentrated $23 \%$ of the burnt spots in the period $(1,256$ spots). Unit 2 presented $13 \%$ of the spots in the evaluated period ( 715 spots). Unit 3 presented $9 \%$ of the values of hot pixels (518 spots).

Although the floodplain environment presented a natural restriction to the fires, spot occurrence was observed in the two Unit ( 2 and 3 ) that flooded during part of the year, being $22 \%$ of the total (Figure $4 a$ ). When comparing the area of each Unit with the average number of spots per thousand hectares (Figure 4b), we verified that Unit 2 had the highest number of spots, although it was the smallest area.

(a)

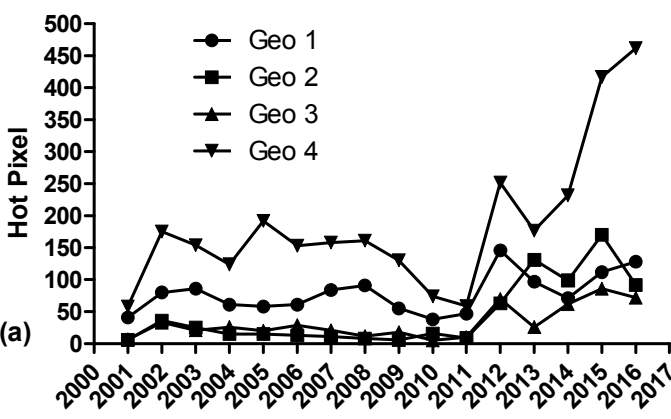

(b)

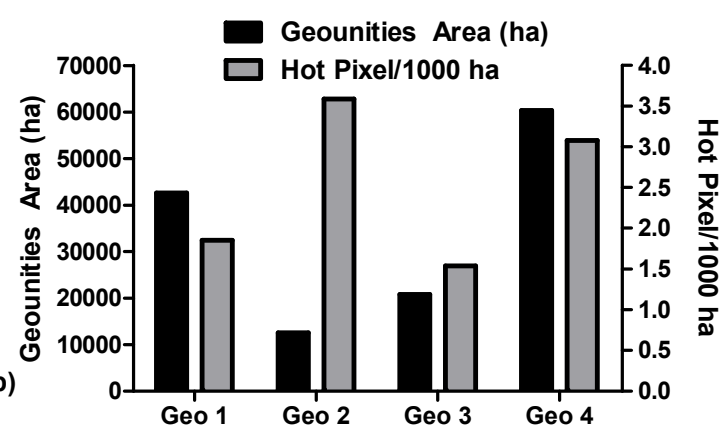

Figure 4. Hot pixels by Unit (a) time series of the number of spots by Unit (b) comparison between the area versus the number of hot pixels in each Unit

\subsection{Seasonal Variation of Rainfall, Deforestation, Hot Pixels and NDVI}

The results presented in Figure 5 show the seasonal variation of rainfall, deforestation, hot pixels and NDVI in the time series evaluated.

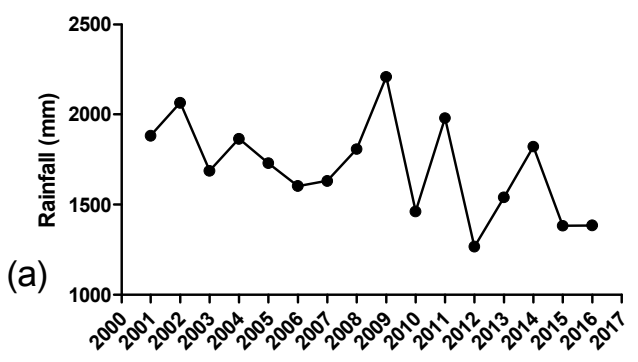

(b)
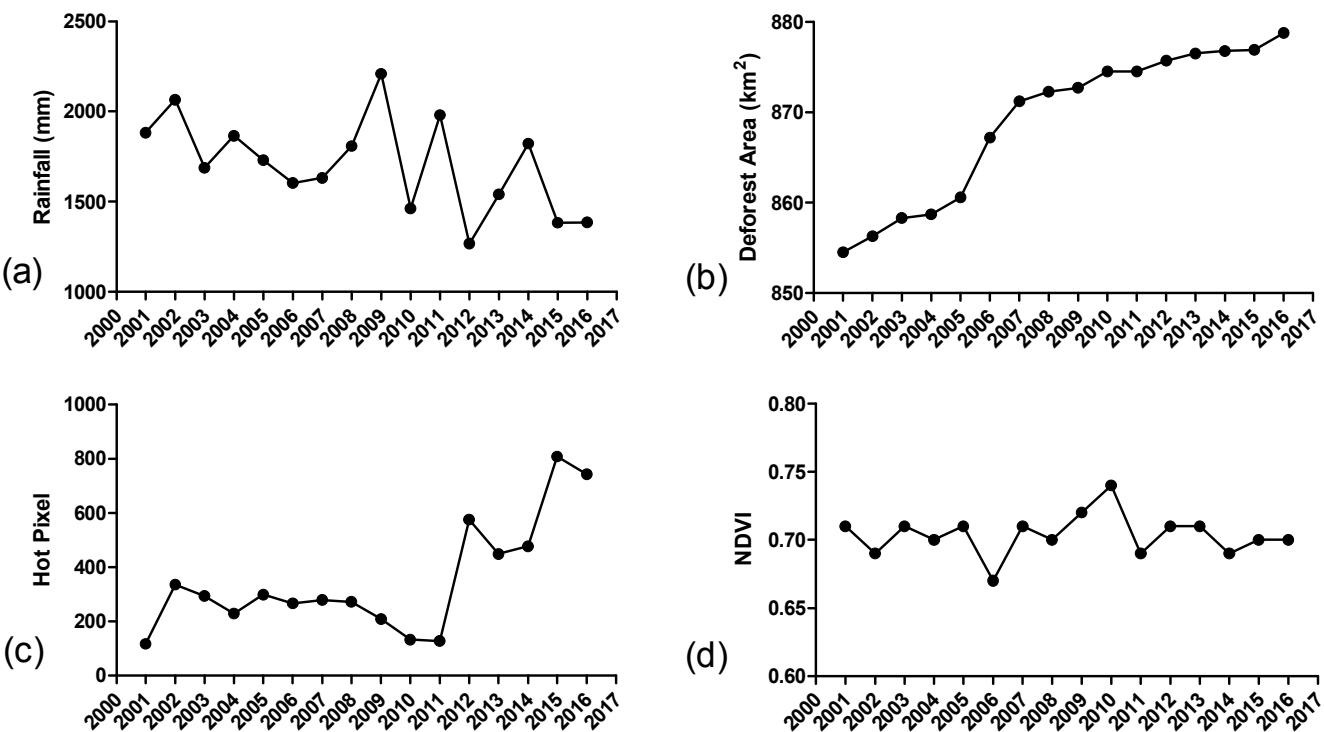

(d)

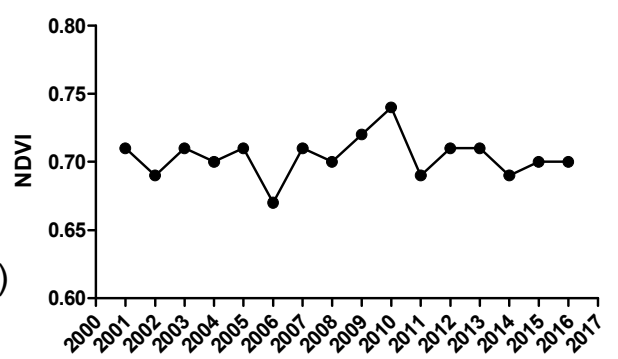

Figure 5. Annual time series from 2001 to 2016: (a) average rainfall (mm); (b) deforested area $\left(\mathrm{km}^{2}\right)$; (c) Number of hot pixels and (d) NDVI 


\subsection{Relation Between Deforestation, Fires, Rainfall, and NDVI}

From the Spearman correlation analysis (Table 2), we verified significant relationships between the spots and the rainfall, spots and NDVI and rainfall and NDVI.

Table 2. Spearman correlation coefficient values $(p<0.05)$, calculated for number of hot pixels; Rainfall, NDVI (Normalized Difference Vegetation Index) and Deforestation (annual deforestation rate)

\begin{tabular}{llll}
\hline Variables & Hot Pixel & Rainfall & NDVI \\
\hline Rainfall & -0.58 & & \\
\hline NDVI & $p=0.02$ & & \\
& -0.64 & 0.53 & $p=0.04$ \\
Deforestation & $p=0.01$ & -0.30 & $p=0.09$ \\
\hline
\end{tabular}

In relation to the Spearman correlation analysis, we present the analysis of the same variables in Figure 6 (a, b, c, d, $\mathrm{e}$, and $\mathrm{f}$ ).

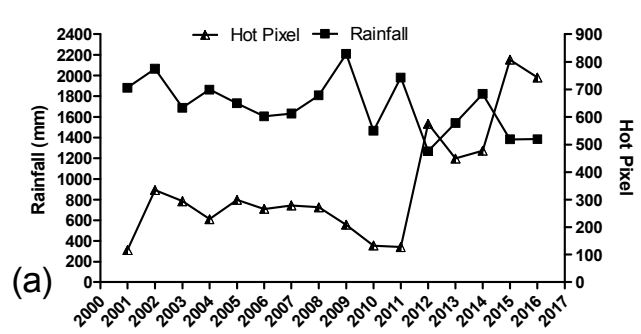

(b)
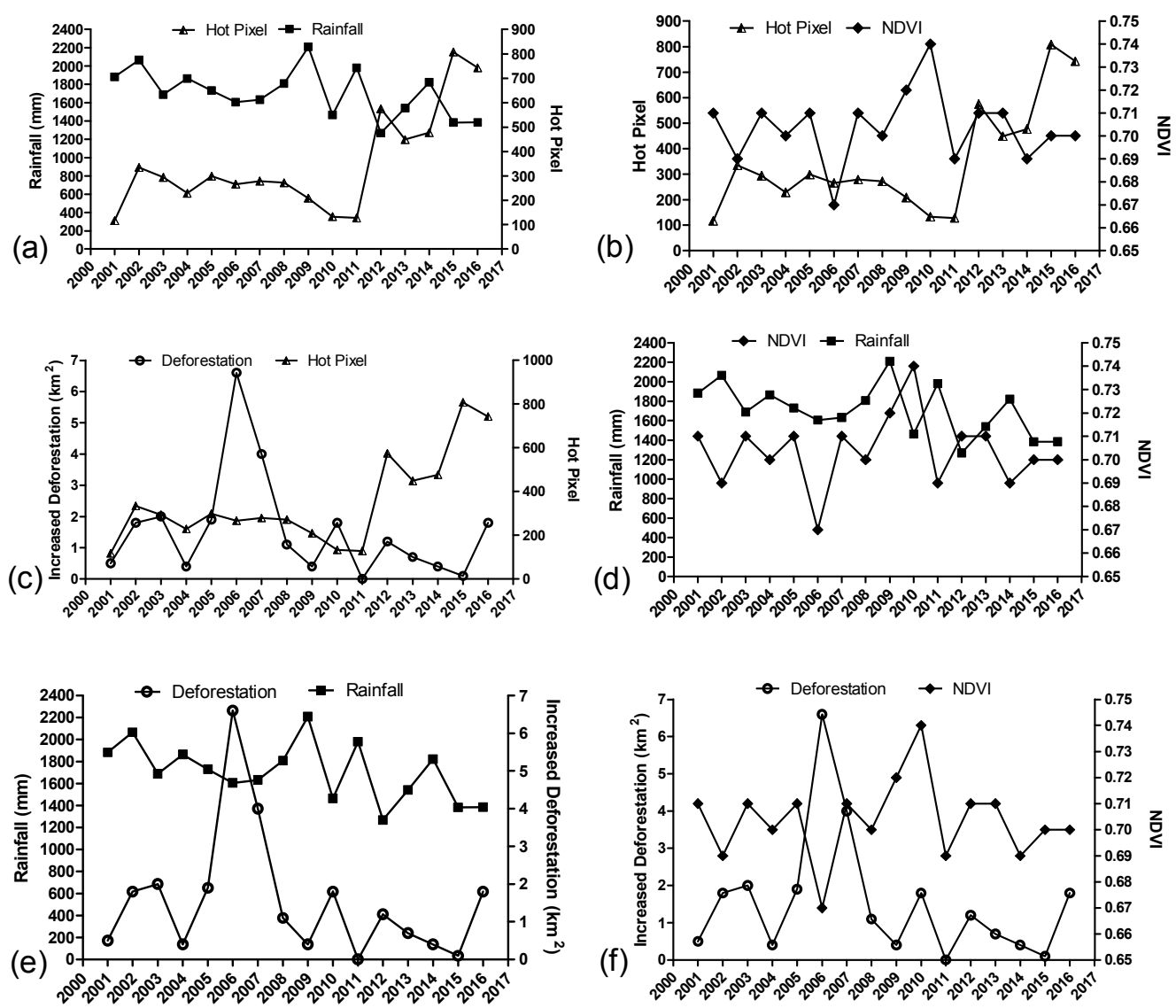

Figure 6. Time series of correlations evaluated; (a) rainfall and hot pixels, (b) hot pixels, and NDVI (c) hot pixels and deforestation, (d) rainfall and NDVI, (e) rainfall and deforestation, (f) deforestation and NDVI

The hot pixels increased significantly during drought periods and decreased during the rainy season (Figure 7a). Rainfall exerted a greater influence on the number of spots from 2012 (Figure 7b). 
(a)

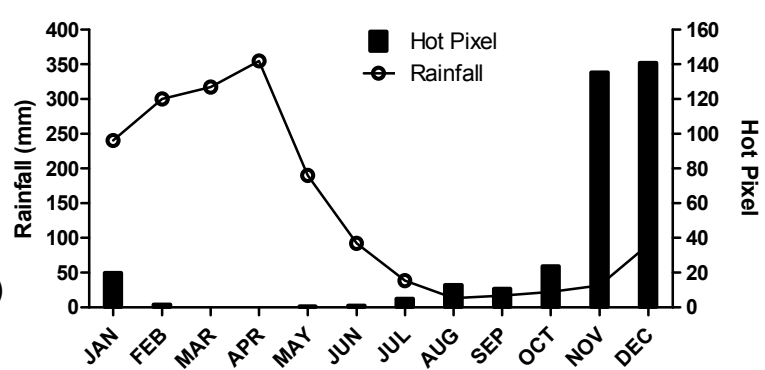

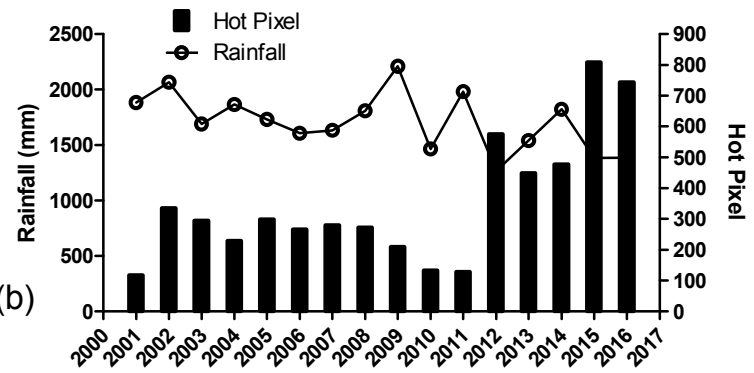

Figure 7. (a) Annual distribution of burnt spots and rainfall; (b) Time series of hot pixels and rainfall

\section{Discussion}

The criteria used by the CPRM to establish the domains and the Geological-Environmental Units our Units, sought to group stratigraphic sets of similar behavior regarding use and occupation. The main objective of this compartmentalization was to meet a wide range of uses and users interested in knowing the environmental implications resulting from the geological foundation (Ramos et al., 2006; Serrano \& Ruiz-Flaño, 2007; Silva et al., 2013). The pattern of grouped distribution of fires may be related to the use of fire as a management practice and soil use conditions, which favor the occurrence of aggregate and specific regions (Trauernicht \& Lucas, 2016; Pereira et al., 2013). The spatial distribution of fires will hardly be completely random because their occurrence in specific areas depends on a series of factors related to the type of protection, prevention practices, characteristics of the region and forest management (Fuentes-Santos et al., 2013; Pereira et al., 2013).

Regarding the number of hot pixels by Unit (Figure 4a), we found that Unit 4 presented the highest number in the period evaluated. It can be justified by the use of burning during land preparation, considering that it was the Unit with the greatest aptitude for agricultural activities where the soils were more fertile, deep, and non-floodable. In the Unit 4, we find that land is used mostly for agricultural activities, where very deep soils are developed, well drained and differentiated from Unit 4 by the low natural fertility and high leaching. Because they are slightly above the average level of rivers, the regions forming Unit 2, their soils were rich in organic matter. Even being flooded part of the period, it was exploited with crops of a short cycle such as the lowland agriculture.

In the Unit 3, there were large lakes, with fluvial and pluvial influence, which could extend far beyond the riverbanks. Here we also found soils that in the dry period presented aptitude for plantations of short cycle, for silviculture and/or natural pasture. In relation to the presence of burnings observed in the Unit that are flooded seasonally, we verified that this is a cultural practice of the region. The lowland agriculture in the Baixada Maranhense was generally developed where arboreal vegetation was non-existent, i.e., in the wetland areas. However, products such as maize and watermelon (consorted with rice) were cultivated in the highest areas, where riparian vegetation was established.

It resulted in deforestation and burning of vegetation (Farias Filho \& Ferraz Jr., 2009) and may explain the presence of hot pixels in the floodable Units. This riparian zone had great ecological importance as it was the transition area between aquatic and terrestrial ecosystems. Furthermore, it was characterized by high biodiversity and provided several important ecosystem services, including water storage and purification and provision of spawning habitats for fish (Garssen et al., 2017).

In this way, we verified that there was a space-time pattern for the hot pixels and that the Units were affected in different ways. Throughout the time-series, it was observed that the areas with the highest soil and relief conditions suitable for agriculture presented a greater number of spots (Units 1 and 4). However, floodable Units 2 and 3 were the most vulnerable to anthropic impacts, as they presented the highest number of spots per hectare. Furthermore, it compromised the riparian vegetation, resulting in network consequences for the local ecosystem.

The annual rainfall presented a decreasing trend, reaching the maximum in 2009 with $2.209 \mathrm{~mm}$ and the minimum in 2012 with $1.268 \mathrm{~mm}$ (Figure 5a). Silva Junior et al. (2016), observed three years of significant rainfall anomaly in the Baixada Maranhense region during 2010, 2012 and 2013 and reported that the 2010 drought affected this area of study. Silva et al. (2016) verified that a change occurred in the hydrological cycle in the last ten years, with the reduction of rainfall during the dry period (Silva et al., 2016).

During the period evaluated, we observed that the rate of deforestation was increasing until $24.7 \mathrm{~km}^{2}$ in the period, with the largest increases occurring in 2006 and 2007 (6.6 and $4.1 \mathrm{~km}^{2}$, respectively) (Figure 5b). Regarding the 
hot pixels, 5.467 spots were detected in the period, with the highest number of spots occurring in 2012, 2015 and 2016, with 575, 808, and 743 spots, respectively (Figure 5c).

Data from satellites such as the Vegetation Indexes, provide the representation of vegetation strength, as well as allow the phenological monitoring favoring the understanding of vegetation response to environmental and anthropic pressures. The Normalized Difference Vegetation Index (NDVI) is one of the most widely used remote sensing tool used for vegetation monitoring. In 2006 an abrupt fall in the NDVI occurred due to the marked increase in the deforested area (Figure 5d). In 2010, the NDVI reached its highest levels, probably because the vegetation responded to the highest rainfall observed in the period in $2009(2.209 \mathrm{~mm})$.

No significant relationships were observed between deforestation and spots, deforestation and rainfall, and deforestation and NDVI. This may be due to the increase in deforestation that occurred in 2006 and 2007. Nevertheless, it may indicate synergy between them. Therefore, a moderate correlation in events with many variables should be considered.

In this study, an inverse and significant correlation was observed between hot pixel and rainfall (Table 2). Regarding the annual average data (Figure 6 a) we observed that there was no modulated behavior between rainfall and hot pixels until the year 2012. This inverse correlation becomes more evident in 2012, when an increase in the number of hot pixel was noticed in years with smaller rainfall values, and vice versa. To complement this analysis, we found it necessary to evaluate this relation with the dry and rainy periods (Figures 7a and 7b).

This analysis showed that the rainfall may interfere, but it was not what determined the number of spots in the region. Mainly from 2012, there was an increase in burning that could not be justified by this climate change. It demonstrated that the relation between hot pixels and rainfall was more qualitative than quantitative. It means that the presence of burn was more related to the season (dry or rainy) but the spot quantity may be more related to anthropic factors.

The presence of hot pixels was strongly associated with the land use. This practice was used to manage pasture and to prepare the soil for agriculture, mainly for short-cycle food crops (Muniz, 2006). Silva Junior et al. (2016) observed in the Baixada Maranhense that the main hot pixels originated from the preparation of the land for the so-called "roça de toco" by small rural producers. It consists on an ancient agricultural technique, passed through generations, that uses burning as a technique of cleaning and preparing the soil for planting.

We observed a strong negative and significant correlation between hot pixels and NDVI (Table 2). Furthermore, they showed an inverse proportional relation where, hot pixels increase, the vegetation indexes tend to decrease (Figure 6b). NDVI is an appropriate index for the study of vegetation, ideal for estimating quantity, quality, and humidity, as well as monitoring these characteristics over time. The index presents good results in the identification of burnt areas (Coutinho et al., 2016). In this study, NDVI values increased in function of the amount of plant material preserved. The highest indexes were observed in years with few hot pixels. This was a quantitative analysis, but the NDVI was already efficient in the identification of scars, even under different levels of vegetation regeneration. The NDVI Data were useful for the verification of recent and old burnt areas (Borini et al., 2015).

There is broad evidence of a relationship between burning and deforestation within the context of land use change and land cover in the Amazon. Nevertheless, there are few studies on spatial distribution and association between these events. We verified that the correlation is practically non-existent between deforestation and hot pixels (Table 2). However, some correlations may be masked by events that conform to the pattern of the rest of the series. This is the case of deforestation that had the highest increase between 2006 and 2007, and the hot pixels presented the highest numbers in 2015 and 2016.

We observed that there is no pattern of association between deforestation and burning in the analyzed period (Figure 6c), where there was a greater increase in deforestation (2006 and 2007) but there was no significant increase in hot pixels. Similarly, in the years in which the greatest hot pixels occurred (2015 and 2016), there was no significant increase in deforestation. Therefore, it demonstrated that this association may be more related to old deforested areas, since secondary vegetation is more susceptible to forest fires than primary forest.

According to Lima et al. (2012), there is a correlation between deforestation and burning, in both recently deforested areas and areas deforested several years ago. Nevertheless, much of the burning process is related to recent deforestation events for the conversion of mature forest to agricultural land. The association between burning and old deforested areas is based on two hypotheses: a) the use of burning for the renovation of existing pasture areas (for weed removal and remineralization of dead biomass) and/or b) the removal of regenerating 
vegetation to new crops or pastures (Aragão \& Shimabukuro, 2010). All these situations emphasize the influence of anthropogenic factors in the process and confirm these hypotheses for our area of study.

There is a significant correlation between NDVI and rainfall (table 2). It was possible to observe a climatic modulation on the vegetation, except in the years of 2006 and 2007 (Figure 6d), because non-standard deforestation increase occurred compared to the rest of the time series. This modulation may have occurred because climatic seasonality, particularly rainfall, influences vegetation seasonality when the annual vegetation growth cycle (identified according to vegetation phenology parameters) is directly related to annual climate seasonality (Bustamante et al., 2012).

In this study, we did not find a significant correlation between deforestation and rainfall because we did not have access to monthly deforestation data, which could demarcate this correlation with the dry and rainy season. Here, an annual series of both variables were used, and it was not possible to observe an association between them (Figure 6e). However, Aragão et al. (2008) verified the relationship between rainfall, deforestation and hot pixels in Amazon. They demonstrate that deforestation reaches its highest annual values approximately three months after the rainy season peak. In this case, there is prognostic action in relation to the dry season peak, allowing time for the fallen wood to dry until the driest month. Then, during the dry season peak (minimum rainfall values), farmers set fire to the dry material on the ground and the hot pixel values reach their maximum.

On broader scales, another relation between rainfall and deforestation were observed. The withdrawal of the forest on a large scale added to the smoke from the fires could promote a reduction in the rainfall over these areas. This chain of events generates a positive feedback loop that increases the vulnerability of the Amazon to climate change (Aragão et al., 2008).

We observed the antagonistic behavior between the deforestation increase and the monthly NDVI average, especially in 2006, when there was an abrupt fall in the NDVI and a marked increase in the deforested area increase (Figure 6f). The development of vegetation indexes, to explore the spectral properties of the vegetation, allowed the inference of biophysical parameters referred to the vegetation of extensive areas of the Earth surface, as well as their responses to the action of geophysical phenomena and to the anthropic influence. Through the NDVI and EVI (Enhanced Vegetation Index) time series, it is possible to show if the changes occurred due to the climatic seasonality caused by the change in the rainfall regime or due to changes in land use such as deforestation and/or burning (Bayma \& Sano, 2015). Therefore, vegetation indexes (EVI and NDVI) are increasingly being used as a large-scale monitoring tool for the changes that have occurred in several ecosystems. Furthermore, they are of great value for the fast detection of recent deforestation due to their high spatial resolution (250 meters), time (1-2 days) and wide range of imaging (2330 km) (Bayma \& Sano, 2015).

The results obtained in this study allow better knowledge of the geodiversity of the Maranhense Amazon floodplain, the anthropic impacts, and their relationship with the environmental variables. The framing of the concept of geodiversity in this context is of special interest because it reflects the understanding of natural diversity and links the concept to the development of policies for conservation and management of protected natural areas.

From the methods used, it was possible to identify the most critical regions, that is, with a higher density of burn occurrence, besides distinguishing the most susceptible and vulnerable Units from the study area. Therefore, it is possible to direct the policies of prevention and combat to forest fires in these specific areas. We verified that there is a space-time pattern for hot pixels and those Units were affected in different ways. Areas with an aptitude for agriculture, presented a greater number of spots (Units 1 and 4). However, floodplain Unit (2 and 3) can be considered more vulnerable to anthropic impacts, by presenting the highest number of spots per hectare, as well as compromising riparian vegetation, bringing net consequences for the local ecosystem.

From the correlations between the environmental and anthropic variables, we verified that rainfall can influence the presence of hot pixels (especially during the drought period). However, spot quantity can be more related to anthropic factors due to the cutting and burning practice for land management. We did not find significant correlations between rainfall and deforestation because we did not have access to monthly deforestation data.

As for NDVI, the highest vegetation indexes were observed in years with few hot pixels. Inversely, in years with the highest rates of deforestation, we found the lowest NDVI. This shows that burning and deforestation directly affect the quantity of vegetation and consequently the forest's environmental diversity. These results show that burning and deforestation are more associated with anthropic factors than to environmental factors within the context of land use change and land cover in Amazon. These anthropic actions imply network consequences with interactions as complex as those governing the biotic and abiotic environments, where the impacts trigger more impacts on a web of variables with spatial and temporal succession. 
Thus, strategies to reduce and control deforestation should include appreciation of the forest for the maintenance of biodiversity, as well as monitoring and inspection policies for the prevention of irregular deforestation and burning practices.

\section{References}

Abreu, F. A., \& Souza, J. D. S. A. (2016). Dinâmica espaço-temporal de focos de calor em duas terras indígenas do Estado de Mato Grosso: Uma abordagem geoespacial sobre a dinâmica do uso do fogo por Xavantes e Bororos. Floresta e Ambiente, 23, 1-10. https://doi.org/10.1590/2179-8087.041813

Aragão, L. E. O., Malhi, Y., Barbier, N., Lima, A., Shimabukuro, Y., Anderson, L., \& Saatchi, S. (2008). Interactions between rainfall, deforestation and fires during recent years in the Brazilian Amazonia. Philosophical Transactions of the Royal Society B, 363, 1779-1785. https://doi.org/10.1098/rstb.2007.0026

Aragão, L. E., \& Shimabukuro, Y. E. (2010). The incidence of fire in Amazonian forests with implications for REDD. Science, 328, 1275-1278. https://doi.org/10.1126/science.1186925

Bayma, A. P., \& Sano, E. E. (2015). Time series of vegetation índices (NDVI and EVI) from MODIS for detecting deforestation in the Cerrado biome. Boletim de Ciências Geodésicas, 21, 797-813. https://doi.org/10.1590/ s1982-21702015000400047

Borini, D. A., Pérez-Cabello, F., \& Rodrigues, M. (2015). Land-use and land-cover dynamics monitored by NDVI multitemporal analysis in a selected southern Amazonian area (Brazil) for the last three decades. Paper presented at the 36th International Symposium on Remote Sensing of Environment, Berlin, Germany. https://doi.org/10.5194/isprsarchives-XL-7-W3-329-2015

Bustamante, J. A., Alvalá, R., \& Von Randow, C. (2012). Seasonal variability of vegetation and its relationship to rainfall and fire in the Brazilian tropical savanna. Paper presented at the 36th International Symposium on Remote Sensing of Environment, Berlin, Germany. https://doi.org/10.5772/35287

Cardozo, F. D. S., Pereira, G., Shimabukuro, Y. E., \& Moraes, E. C. (2014). Analysis and Assessment of the Spatial and Temporal Distribution of Burned Areas in the Amazon Forest. Remote Sens., 6, 8002-8025. https://doi.org/10.3390/rs6098002

Carvalho Neta, R. N. F., Dantas, J. G., Sousa, D. B. P., Andrade, T. S. O. M., \& Farias Filho, M. S. (2015). Área de Proteção Ambiental da Baixada Maranhense: Desafios Atuais e Futuros para a Gestão dos Recursos Aquáticos (Unpublished dissertation). Universidade Estadual do Maranhão, São Luís, Brazil.

Cohen, J. (1988). Statistical power analysis for the behavioural sciences. New York, New York.

Coutinho, M. A. N., Fernandes, A. C. G., Santos, V. G., \& Nascimento, C. R. (2016). Análise comparativa dos índices de vegetação NDVI, SAVI, RATIO E IAF para identificação de queimadas. Caderno de Ciências Agrárias, 8, 70-81.

Farias Filho, M. S. (2013). Urban expansion and environmental impacts on coast north of São Luís (Ma). Raega-O Espaço Geográfico em Análise, 46, 07-24. https://doi.org/10.5380/raega.v46i1.52552

Farias Filho, S., \& Ferraz Júnior, A. S. L. (2009). A cultura do arroz em sistema de vazante na Baixada Maranhense, periferia do sudeste da Amazônia. Pesquisa Agropecuária Tropical, 39, 82-91.

Fuentes-Santos, I., Marey-Pérez, M. F., \& Gonzáles-Manteiga, W. (2013). Forest fire spatial pattern analysis in Galicia (NW Spain). Journal of Environmental Management, 128, 30-42. https://doi.org/10.1016/j.jenvman. 2013.04.020

Garssen, A. G., Baattrup-Pedersen, A., Riis, T., Raven, B. M., Hoffman, C. C., Verhoeven, J. T., \& Soons, M. B. (2017). Effects of increased flooding on riparian vegetation: Field experiments simulating climate change along five European lowland streams. Global Change Biology, 23, 3052-3063. https://doi.org/10.1111/ gcb. 13687

Gray, M. (2004). Geodiversity: Valuing and conserving abiotic nature. Philadelphia, Pennsylvania

IBGE (Instituto Brasileiro de Geografia e Estatística). (2011a). Geomorfologia: Mapa geomorfológico do estado do Maranhão. Retrieved from https://ww2.ibge.gov.br/home

IBGE (Instituto Brasileiro de Geografia e Estatística). (2011b). Pedologia: Mapa exploratório de solos do estado do Maranhão. Retrieved from https://ww2.ibge.gov.br/home

Klein, E. L., \& Sousa, C. S. D. (2012). Recursos minerais. Geodiversidade do Estado do Maranhão (1st ed.). Teresina, Piauí, Brazil. 
Lima, A., Silva, T. S. F., Feitas, R. M., Adami, M., Formaggio, A. R., \& Shimabukuro, Y. E. (2012). Land use and land cover changes determine the spatial relationship between fire and deforestation in the Brazilian Amazon. Applied Geography, 34, 239-246. https://doi.org/10.1016/j.apgeog.2011.10.013

Muniz, F. H. (2006). A vegetação da região de transição entre a Amazônia e o Nordeste, diversidade e estrutura. In Uema (Ed.), Agroambientes de transição entre o trópico úmido e o semi-árido do Brasil: Atributos, alterações e uso na produção familiar (pp. 53-69). São Luís, Brazil.

Pereira, A. A., Barros, D. A., Junior, F. W. A., Pereira, J. A. A., \& Reis, A. A. (2013). Análise da distribuição espacial de áreas queimadas através da função K de Ripley. Scientia Forestalis, 41, 445-455.

Piromal, R. A. S., Rivera-Lombardi, R. J., Shimabukuro, Y. E., Formaggio, A. R., \& Krug, T. (2008). Utilização de dados MODIS para a detecção de queimadas na Amazônia. Acta Amazonica, 38, 77-84. https://doi.org/ 10.1590/s0044-59672008000100009

Ramos, M. A. B., Theodorovicz, A., Marques, V. J., Orlandi, V., Pfaltzgraff, P. A. D. S., Dantas, M. E., \& Silva, C. R. D. (2006). Metodologia, estruturação da base de dados e organização das informações em SIG do Projeto Geodiversidade do Brasil. Retrieved from http://rigeo.cprm.gov.br/xmlui/bitstream/handle/doc/16855/procedi mentos_SIG_Geodiversidade.pdf? sequence=1

Serrano, E., \& Ruiz-Flaño, P. (2007). Geodiversity: A theoretical and applied concept. Geographica Helvetica, 62, 140-147. https://doi.org/10.5194/gh-62-140-2007

Silva Junior, C. H. L., Freire, A. T. G., Rodrigues, T. C. S., Viegas, J. C., \& Silva Bezerra, D. (2016). Dinâmica das Queimadas na Baixada Maranhense. Revista de Geografia e Interdisciplinaridade, 2, 355-375. https://doi.org/ 10.18766/2446-6549/interespaco.v2n5p355-375

Silva, C. R. D. (2008). Geodiversidade do Brasil: Conhecer o passado, para entender o presente e prever o futuro. Rio de Janeiro, Brasil.

Silva, F. B., Santos, J. R. N., Feitosa, F. E. C. S., Silva, I. D. C., Araújo, M. D., Guterres, C. E., ... Neres, R. L. (2016). Evidências de mudanças climáticas na região de transição Amazônia-Cerrado no estado do Maranhão. Revista Brasileira de Meteorologia, 31, 330-336. https://doi.org/10.1590/0102-778631320150149

Silva, J. P., Pereira, D. I., Aguiar, A. M., \& Rodrigues, C. (2013). Geodiversity assessment of the Xingu drainage basin. Journal of Maps, 9, 254-262. https://doi.org/10.1080/17445647.2013.775085

Trauernicht, C., \& Lucas, M. (2016). Wildfire Ignition Density Maps for Hawaii. Forest and Natural Resource Management. Retrieved from https://www.ctahr.hawaii.edu/oc/freepubs/pdf/RM-21.pdf

Viegas Carvalho, J., Silva, T. R. C., \& Feitosa Cordeiro, A. (2012). Modificações socioambientais decorrentes da construção da barragem do rio Pericumã, na área de influência da cidade de Pinheiro-Estado do Maranhão-Brasil. Revista Geográfica de América Central, 2, 1-16.

Vieira, I. C. G., Silva, J. M. C. D., \& Toledo, P. M. D. (2005). Estratégias para evitar a perda de biodiversidade na Amazônia. Estudos Avançados, 19, 153-164. https://doi.org/10.1590/s0103-40142005000200009

\section{Copyrights}

Copyright for this article is retained by the author(s), with first publication rights granted to the journal.

This is an open-access article distributed under the terms and conditions of the Creative Commons Attribution license (http://creativecommons.org/licenses/by/4.0/). 